www.jmscr.igmpublication.org

Impact Factor 5.244

Index Copernicus Value: 5.88

ISSN (e)-2347-176x ISSN (p) 2455-0450

crossref DOI:_http://dx.doi.org/10.18535/jmscr/v4i5.11

Journal Of Medical Science And Clinical Research

IGM Publication

An official Publication of IGM Publication

\title{
The Prevalence of Shigella and Enterotoxigenic E. Coli Infection amongst Patients Attending a General Hospital, North Bank Makurdi Nigeria
}

\author{
Authors \\ Agbulu, C. O' ${ }^{1}$, Okoko, J. A ${ }^{2}$, Adokwu, .E. E ${ }^{3}$ \\ ${ }^{1,3}$ Dept of Biological Sciences, College of Science,Federal University of Agriculture, \\ Makurdi, Benue State. Nigeria \\ ${ }^{2}$ Paediatrics Department, Federal Medical Centre, Makurdi, Benue, State Nigeria \\ Corresponding Author \\ Email:xtybul@yahoo.com
}

\begin{abstract}
The prevalence of Enterotoxigenic E. coli and Shigella spp infection was conducted at General Hospital Makurdi, Benue State, Nigeria. One hundred and eight (108) fecal specimens from consenting clinically diagnosed patients from both sexes and of all age groups were collected. Each feacal sample was inoculated onto Salmonella Shigella agar (SSA agar) and Triple sugar iron agar (TSIA). Media were incubated at $37^{\circ} \mathrm{c}$ for $24 \mathrm{hr}$. Isolates were identified using standard microbiological techniques. For the study data, Chi-square ( $\chi 2)$ or Fisher's exact test as appropriate and odd ratio analysis were used for analysis. The prevalence of Enterotoxigenic E. coli and Shigella spp from the sample collected was $12.5 \%$ each. Favorable factors found to be associated with infection included the wetter seasons of the year and asymptomatic carriage of infection. Gender is not a statistically significant $(p>0.05)$ risk factor of infection in this study. There was a strong evidence of relationship between bacteria isolate and source of drinking water of the feacal sample. This suggests that it is necessary to drink safe and purified water free from pathogenic organisms as well as washing hands with antibacterial soap after going to the toilet or shaking hands since it can be a source for the transfer of bacteria from one person to the other.

Keywords: Enterotoxigenic E.coli, Shigella spp, General Hospital Makurdi
\end{abstract}

\section{Introduction}

Shigella is an infectious food-borne pathogen which causes a severe diarrhea illness called shigellosis (Grondin et al., 2012). Shigella is a genus of Gram-negative, facultative anaerobic, non-spore forming, non-motile, rod-shaped bacteria related to Salmonella. The genus is named after Kiyoshi Shiga, who first discovered it in 1897 (Yabuuchi, 2002). Four species of Shigella exist (Shigella dysenteriae, Shigella flexneri, Shigella boydii and Shigella sonnei) which cause shigellosis. Shigella flexneri is endemic in many developing countries and causes higher mortality than other Shigella species (Bennish, 1991). Escherichia coli is a Gramnegative, facultative anaerobic, rod-shaped bacterium commonly found in the lower intestine of warm-blooded organisms(Singleton, 1999). Most Escherichia coli strains are harmless, but some serotypes can cause serious food poisoning in their hosts, and are occasionally responsible for product recalls due to food contamination (Vogt 
and Dippold, 2005). Escherichia coli and other facultative anaerobes constitute about $0.1 \%$ of gut flora and fecal-oral transmission is the major route through which pathogenic strains of the bacterium cause disease (Eckburg et al., 2005). However, in other parts of the body, Escherichia coli can cause serious disease, such as urinary tract infections, bacteraemia and meningitis. (Nataro, 1998). Pathogenic Escherichia coli strains are categorized into pathotypes. Six pathotypes are associated with diarrhea and collectively are referred to as diarrheagenic $E$. coli (Center for Disease Control and Prevention, 2006). Shiga toxin-producing E. coli (STEC) may also be referred to as Verocytotoxin-producing $E$. coli (VTEC) or enterohemorrhagic E. coli (EHEC). This pathotype is most associated with foodborne outbreaks. They include Enterotoxigenic E. coli (ETEC), Enteropathogenic E. coli (EPEC), Enteroaggregative E. coli (EAEC), Enteroinvasive E. coli (EIEC), Diffusely adherent E. coli (DAEC) . Escherichia coli encompass an enormous population of bacteria that exhibit a very high degree of both genetic and phenotypic diversity. Escherichia coli remain one of the most diverse bacterial species: only $20 \%$ of the genome is common to all strains (Lukjancenko, 2010).

Both Escherichia coli and Shigella spp infections produce potent enterotoxin and shigatoxin respectively which causes severe and lifethreatening disease. These species are related and have some similarity in their symptomology, but Escherichia coli infections are a serious problem in children (Wright, 2005). These infections are responsible for approximately 165 million cases of diarrhea annually, of which 163 million are in developing countries and (Peirano et al., 2006). In developing countries, $69 \%$ of all cases are children under the age of 5 years (Peng and Chompook, 2005).

Many individuals who are infected with Shigella expand fever, painful, bloody or mucous diarrhea, and stomach cramps (Mandomando et al., 2007) while the main characteristic of Enterotoxigenic
E. coli disease is a watery diarrhea, other symptoms include abdominal cramps, low-grade fever, nausea, headache, muscle ach. Primarily, shigellosis and Enterotoxigenic E. coli are transmitted from person to person through the fecal-oral route, but it may also spread indirectly by fecal contamination of water or food (Frank et al., 2011). Little data is available for the prevalence of Enterotoxigenic E. coli and Shigella infections in Makurdi Metropolis.

\section{Objectives}

- To determine the prevalence of Shigella spp and Enterotoxigenic E. coli infection found in the stool of clinically diagnosed patients at general hospital Makurdi, Benue state.

- Determine the association of the disease with age and sex distribution among clinically diagnosed patient at General Hospital North Bank Makurdi, Benue state.

\section{Materials and Methods}

\section{Study Area and Study Population}

The study was conducted in the General Hospital, North Bank, one of the oldest and largest tertiary hospitals in Makurdi under North Bank district. The study population consisted of patients of all age group residing in the Makurdi area were the study population irrespective of sex and sociodemographic status presented in Makurdi. The groups considered for this test are: Farmers, civil servants, skilled workers, students, house wives, tailors, hair dressers and traders.

\section{Ethical Consent}

Ethical consent was sought from the patients and confidentiality was observed.

\section{Data Collection}

Demographic information about each volunteer was obtained using a structured questionnaire. Some such information includes age, marital status, occupation, educational level, gender, source of drinking water. 


\section{Sample Collection}

A single, fresh, whole stool specimen (at least 3 $\mathrm{ml}$ or grams, ideally $10 \mathrm{ml}$ or grams) was collected from One hundred and nine patients who enrolled in General Hospital, Makurdi. A faecal swab was then placed in Cary-Blair medium in a plastic screw top test tube. Stool samples were then transported to the microscopy section for screening common enteric pathogens such as ETEC E. coli and Shigella spp maintaining standard protocols. Optimal cool temperature was strictly maintained from the point of collection of stool sample to successful submission.

\section{Media Preparation / Plates preparation}

According to manufacturers instructions, sixty three grams $(63 \mathrm{~g})$ of powered salmonella Shigella agar was weighed and dispersed in $1000 \mathrm{~m} / \mathrm{s}$ in distilled water. This was boiled with frequent agitation to dissolve the medium completely and cooled to about $45^{\circ} \mathrm{c}$ or body temperature. It was then mixed and poured into sterile Petri dishes or plate and allowed to solidify.

\section{Sterilization of equipment}

The equipment used were washed, and sterilized in the laboratory using a hot-air oven at $160^{\circ} \mathrm{c}$ for 2 hours to avoid contamination.

\section{Preparation of Peptone water}

Fifteen grams $(15 \mathrm{~g})$ of dehydrated peptone water powder was weighed and dissolved in $1000 \mathrm{mls}$ of distilled water, this preparation was gently heated to dissolve the medium completely sterilize by autoclaving at $15 \mathrm{psi}$ at $21^{\circ} \mathrm{c}$ for $15 \mathrm{mins}$ this was cooled to about $45^{\circ} \mathrm{c}$ or body temperature and $5 \mathrm{mls}$ each was dispense into bijou bottle for broth culture preparation.

For ETEC, stool samples were plated onto MacConkey agar and the plates were incubated at $37^{\circ} \mathrm{c}$ for 18 hours. Lactose-fermenting individual colonies, morphologically resembling E. coli, were tested.

Shigella species were isolated and identified in the enteric microbiology laboratory by using standard biochemical and microbiological methods. Stool specimens were inoculated in Shigella-Salmonella agar plates and incubated overnight at $37^{\circ} \mathrm{c}$. Non lactose-fermenting colonies; characteristically resembling Shigella, were inoculated into triple sugar iron agar tube.

\section{Triple sugar iron agar (TSIA)}

This is used to determine the ability of an organism to attack a specific carbohydrate incorporated into basal growth medium with or without production of gas, along with the determination of possible hydrogen sulphide production.

Sixty five grams of dehydrated triple sugar iron agar was weighed and dissolved in $1000 \mathrm{mls}$ of distilled water. It was gently heated to dissolve the medium and completely distributed into tubes, sterilized by autoclaving at $10 \mathrm{psi}\left(115^{\circ} \mathrm{c}\right)$ for 15minites. Triple sugar iron agar slant was inoculated with the test organism by stabbing the butt and streaking the surface of the slant. This was incubated at $37^{\circ} \mathrm{c}$ for 24 hours. Glucose is fermented only when butt appear yellow and the slant is red. Also, when glucose, lactose and/or sucrose is fermented, both butt and slant appears yellow and when there is no action, butt and slant appears red in color. Hydrogen supplied production was indicated by the presence of black precipitate (CDC, 2009).

\section{Inoculation}

The prepared SSA where dried in hot air oven at $37^{\circ} \mathrm{c}$ to remove excess moisture, the plate where labeled 1-108 and the stool sample culture was inoculated in the respective plate with the aid of a sterile wire loop. The plates were incubated for $24 \mathrm{hrs}$ at $37^{\circ} \mathrm{c}$.

\section{Morphological Characteristics}

After incubation time of the plates were observed morphologically for color, odour, obesity, consistency, size, shape, e.t.c

Characterization and identification of isolates 
Morphological descriptions of colonies were carried out, physical observation and other biological tests.

\section{Gram staining}

A drop of distilled water was placed on a clean glass slide, a wire loop was flamed and used to pick a small portion of the colony from the cultured plate to make a thin smear, which heatwas fixed to dry. These smears were flood with crystal violet for 30-60 seconds and washed with tap water and flood with Lugol's iodine for another 30-60 seconds and washed with tap water and decolourized with alcohol (ethanol) for 20 seconds and washed with tap water and lastly counter stained with safranine for 20 seconds, washed with tap water and kept to air dry. These were later examined under a light microscope using an oil immersion and the morphological characteristics were observed and recorded.

\section{Biochemical Identification}

All biochemical test were done as described in Cheesbrough (2000) .Biochemical reactions of each bacterial isolate were verified using the different biochemical tests. For each sample, discrete colonies of the bacterial isolates were picked with a wire-loop and sub-cultured for biochemical analysis. The following tests were carried out:

\section{Indole test}

Indole test was used in the identification of enterobacteria. Most strains of Escherichia coli species break down the amino acid tryptophan with the release of indole.

The test organism was inoculated in a bijou bottle containing $3 \mathrm{ml}$ of sterile tryptone water and inoculated at $35-37^{\circ} \mathrm{c}$ for 48 hours. This was done by adding $0.5 \mathrm{ml}$ of kovac's reagent and shaked gently and observed for a red colour in the surface layer within 10minutes. The appearance of a red colour in the surface layer of the bijou bottle confirmed a positive indole and no colour appearance confirmed a negative indole.

\section{Motility test}

This is used to determine if an organism is motile or non motile. Motility test agar (nutrient agar) was inoculated with a Small bit of the test organism and stab to the bottom of the bottle of the semi solid nutrient agar using a sterile straight wire. The straight wire is pulled out in the same line from the rest agar and incubated aerobically at $37^{\circ} \mathrm{c}$ for 48 hours. The motile bacteria spreads throughout the medium (true motility), while the non motile bacteria grow only at the line of the stab.

\section{Hydrogen Sulphide Production}

Few colonies each of suspected organisms where transferred into TSIA and incubated at $37^{\circ} \mathrm{c}$ for 24hrs. it was then obsereved for presence of blacking Hydrogen Sulphide) and gas production. TSIA was obsereved fo Maltose, sucrose and lactose fermentation. Shigella shows red slope, Yellow booth and negative gas production. E. coli shows yellow booth. No hydrogen sulphide but gas production. The evidence of gas production shows crack.

\section{Questionaire}

Questionaires were used to get information on the sources of the patients' sources of drinking water, age and gender.

\section{Statistical Analysis}

Descriptive analytic technique (percentages) was used. Data obtained were analyzed using Chisquare $\left(\chi^{2}\right)$ or Fisher's exact test as appropriate and odd ratio analysis using the statistical software INSTAT. A P-value of less than 0.05 (i.e. $\mathrm{P}<0.05$ ) was considered to be statistically significant, while $\mathrm{P}$-value more than $0.05(\mathrm{P}>$ 0.05) was considered to be statistically not significant. Statistical Package for Social Sciences (Version 21) was used for data entry and subsequent analysis. 


\section{JMSCR Vol||04||Issue||05||Page 10444-10455||May}

\section{Results}

The results from the total of one hundred and eight (108) stool samples shows the morphological characteristics of the isolated bacteria namely; (Escherichia coli, Salmonella spp, Shigella spp, Proteus spp) (Table 1)

Table 2 shows the biochemical characteristics of bacteria isolated from the samples collected.

Table 3 shows Gram reaction, shape of cell and arrangement of bacteria isolated from stool sample
Table 4 shows the different types of bacteria isolated from stool specimens of clinical diagnosed patient screened in this study. On the whole, one hundred and one (101) stool specimens yielded no growth of microbial colonies. Seven (7) specimens yielded microbial growth. The highest prevalence of bacterial growth was recorded for salmonella spp $(4,50 \%)$ next to Proteus $\operatorname{spp}(2,25 \%)$ which is more than Escherichia coli and Shigella that is our interest.

TABLE 1: MORPHOLOGICAL CHARACTERISTICS OF THE ORGANISMS ISOLATED

\begin{tabular}{lll}
\hline S/NO & COLONY CHARACTERISTICS & PROBABLE ORGANISM \\
\hline 1 & $\begin{array}{l}\text { Pink to rose-red colonies, may } \\
\text { have bile precipitate. LF }\end{array}$ & Escherichia coli \\
2 & $\begin{array}{l}\text { Colorless colonies with } \\
\text { black centers. NLF }\end{array}$ & Salmonella typhimurium \\
3 & Colorless colonies. NLF & Shigella flexneri \\
4 & Colorless, transparent. & Proteus spp \\
\hline
\end{tabular}

NLF-Non-lactose fermenter

LF-Lactose Fermenter

TABLE 2: BIOCHEMICAL CHARACTERISTICS OF BACTERIA ISOLATED FROM STOOL SAMPLE.

\begin{tabular}{llllll}
\hline S/no & Motility & Indole & $\begin{array}{l}\text { Hydrogen } \\
\text { production }\end{array}$ & sulphide & Probable organism \\
\hline $\mathbf{1}$ & $+\mathrm{ve}$ & $+\mathrm{ve}$ & $+\mathrm{ve}$ & Shigella flexneri \\
$\mathbf{2}$ & $+\mathrm{ve}$ & $+\mathrm{ve}$ & $+\mathrm{ve}$ & ETEC Escherichia coli \\
\hline
\end{tabular}

KEY

+ve-positive

-ve-Negetive

TABLE 3: GRAM REACTION AND SHAPE OF CELL OF GRAM NEGATIVE BACTERIA ISOLATED

\begin{tabular}{lllll}
\hline S/No & GRAM & SHAPE OF CELL & ARRANGEMENT & $\begin{array}{l}\text { PROBABLE } \\
\text { ORGANISM }\end{array}$ \\
& REACTION & & & E. coli \\
$\mathbf{1}$ & $-\mathrm{ve}$ & Rods & Clusters & Shigella spp \\
\hline
\end{tabular}

KEY

+ve-positive

-ve-Negetive 
TABLE 4: DISTRIBUTION OF ORGANISMS ISOLATED FROM STOOL SPECIMENS IN GENERAL HOSPITAL NORTH

\section{S/No Organisms}

$1 \quad$ Escherichia coli

$2 \quad$ Shigella spp

3

4

Proteus

Salmonella spp

Total

8

100

The prevalence of infection with E. coli and Shigella spp by source of drinking water among clinical diagnosed patients within General Hospital Makurdi districts of Benue State, though out of the organisms of research interest, Salmonella spp and Proteus spp were found as shown in Table 5. Out of the 108 persons screened, $1(0.9 \%)$ were infection gotten from drinking stream water while $2(1.9 \%)$ and $4(3.7 \%)$ where borehole water infection. No infection was found among persons that drank from rivers and well water. Here, the significance level $(0.000)$ for the Chi-Square value (35.668) is less than the 0.05 cut off, and hence, there is a significant relationship between the source of drinkable water
Frequency

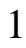

1

2

4
Percent $(\%)$

12.5

12.5

25

50 by bacteria isolated and infection with the pathogen.

Table 6 shows the observed frequencies of infection which were compared with the various age groups of patients. A cursory look at the table reveals that $1(0.9 \%)$ persons in the 21-30 age group were infected with E. coli and Shigella spp, while $1(0.9 \%)$ and $1(0.9 \%)$ persons within the 21 30 and 31-40 age bracket were infected with proteus and salmonella respectively, The percentage distribution of persons infected shows that there is moderate difference in the proportion of people living with E. coli and Shigella spp by person's age.

TABLE 5: CONTINGENCY TABLE OF OBSERVED FREQUENCY OF INFECTION OF BY SOURCE OF DRINKING WATER IN GENERAL HOSPITAL MAKURDI $(\mathrm{N}=108)$

\begin{tabular}{llllllll}
\hline & \multicolumn{2}{c}{ Shigella spp/ E. coli } & Proteus & Salmonella & Total & $\begin{array}{l}\text { Chi- } \\
\text { Square }\end{array}$ & $\begin{array}{l}\text { P- } \\
\text { Value }\end{array}$ \\
& $\begin{array}{l}\text { No. } \\
\text { Infected }\end{array}$ & $\begin{array}{l}\text { (\%) } \\
\text { Infected }\end{array}$ & & & & & \\
\hline Source of Water & & & & & & & \\
Borehole & $0(0.0 \%)$ & $95(88.0 \%)$ & $2(1.9 \%)$ & $4(3.7 \%)$ & $101(93.5 \%)$ & & $0.00 *$ \\
Stream & $1(0.9 \%)$ & $2(1.9 \%)$ & $0(0.0 \%)$ & $0(0.0 \%)$ & $3(2.8 \%)$ & & 35.668 \\
Well & $0(0.0 \%)$ & $3(2.8 \%)$ & $0(0.0 \%)$ & $0(0.0 \%)$ & $3(2.8 \%)$ & & \\
River & $0(0.0 \%)$ & $1(0.9 \%)$ & $0(0.0 \%)$ & $0(0.0 \%)$ & $1(0.9 \%)$ & & \\
Total & $1(0.9 \%)$ & $101(93.5 \%)$ & $2(1.9 \%)$ & $4(3.7 \%)$ & $108(100.0 \%)$ & \\
\hline
\end{tabular}

* Statistically significant $\quad \mathrm{p}<0.05$ 
TABLE 6: CONTINGENCY TABLE OF OBSERVED FREQUENCY OF INFECTION BY AGE OF PATIENTS IN GENERAL HOSPITAL MAKURDI $(\mathrm{N}=108)$

\begin{tabular}{llllllll}
\hline \multicolumn{3}{l}{ Shigella spp/ E. coli } & Proteus & Salmonella & Total & $\begin{array}{l}\text { Chi- } \\
\text { Square }\end{array}$ & $\begin{array}{l}\text { P- } \\
\text { Value }\end{array}$ \\
& No.(\%) Infected & Not Infected & & & & & \\
\hline $\mathbf{0 - 1 0}$ & $0(0.0 \%)$ & $25(23.1 \%)$ & $0(0.0 \%)$ & $1(0.9 \%)$ & $26(24.1 \%)$ & & \\
$\mathbf{1 1 - 2 0}$ & $0(0.0 \%)$ & $12(11.1 \%)$ & $0(0.0 \%)$ & $0(0.0 \%)$ & $12(11.1 \%)$ & & \\
$\mathbf{2 1 - 3 0}$ & $1(0.9 \%)$ & $37(34.3 \%)$ & $1(0.9 \%)$ & $1(0.9 \%)$ & $40(37.0 \%)$ & & \\
$\mathbf{3 1 - 4 0}$ & $0(0.0 \%)$ & $14(13.0 \%)$ & $1(0.9 \%)$ & $1(0.9 \%)$ & $16(14.8 \%)$ & 31.959 & \\
$\mathbf{4 1 - 5 0}$ & $0(0.0 \%)$ & $9(8.3 \%)$ & $0(0.0 \%)$ & $0(0.0 \%)$ & $9(8.3 \%)$ & & \\
$\mathbf{5 1 - 6 0}$ & $0(0.0 \%)$ & $0(0.0 \%)$ & $0(0.0 \%)$ & $1(0.9 \%)$ & $1(0.9 \%)$ & & \\
$\mathbf{6 0 - a b o v e}$ & $0(0.0 \%)$ & $4(3.7 \%)$ & $0(0.0 \%)$ & $0(0.0 \%)$ & $4(3.7 \%)$ & & \\
Total & $1(0.9 \%)$ & $101(93.5 \%)$ & $2(1.9 \%)$ & $4(3.7 \%)$ & $108(100.0 \%)$ & \\
\hline
\end{tabular}

* Statistically significant $\quad \mathrm{p}<0.05$

The observed frequencies of the bacteria in relation to gender of persons are given in Table 7 , which reflects the Fisher's exact test values for the two nominal variables ("sex of persons" and $E$. coli and Shigella spp infection") as well as the P- value and Odds ratio and $95 \%$ confidence interval. Since the 2-sided $\mathrm{P}$-value $(\mathrm{P}=0.50)$ is greater than 0.05 cut off, there is not a significant association between the two tested variables.

TABLE 7: FREQUENCIES OF E. COLI AND SHIGELLA SPP INFECTION IN RELATION TO GENDER OF PATIENTS SCREENED

\begin{tabular}{llllllll}
\hline Gender & $\begin{array}{l}\text { Number } \\
\text { Screened }\end{array}$ & $\begin{array}{l}\text { Number } \\
\text { Infected }\end{array}$ & $\begin{array}{l}\text { (\%) } \\
\text { Odd } \\
\text { Ratio }\end{array}$ & $\begin{array}{l}\text { 95\% } \\
\text { Limit }\end{array}$ & Confidence & P-Value \\
\hline Male & 54 & $1.90 \%$ & 0.981 & $0.946-1.018$ & 0.5 \\
Female & 54 & $0.00 \%$ & & & & \\
\hline * Statistically significant & $\mathrm{p}<0.05$ & & & &
\end{tabular}

\section{Discussion}

Shigella spp and ETEC are the known major etiologic agents that are responsible for deaths particularly in children (Parashar, 2003). There is a significant relationship between sources of drinking water and bacteria isolated. Out of a total of one hundred and nine (108) stool samples, only $1(0.9 \%)$ were found infected with Enterotoxigenic E. coli and Shigella spp. The low infection rate may be attributed to the dry season. Unseasonable heavy rain falls may cause flooding and contamination of sources of drinking water.

In Table 6 the observed frequencies of infection with Enterotoxigenic E. coli and Shigella spp were compared with the various age groups of patients screened. Since the significance level 0.022 is greater than the $\mathrm{P}<0.05$ cut off, it can be concluded that Enterotoxigenic E. coli and Shigella spp infection are dependent of person's age. According to Slutsker et al., 1997, agespecific isolation proportions from fecal specimens in adults are equivalent to population based incidence rates, although their findings suggest that infections were seen more in adults 50 years and above. In another study, however, the age specific annual incidence rate was highest for children younger than 5 years of age (Ostroff et al., 1989). It can be inferred from the result obtained in Table 7 that since the P- value of 0.5 is greater than 0.05 cut off, there is no significant relationship between the sex of persons and their infection with the organism. Su and Brandt (1995) have also reported in their studies that Enterotoxigenic E. coli and Shigella spp infection 
generally affects both sexes equally. Thus it can be deduced that persons' gender does not constitute a risk factor for Enterotoxigenic E. coli and Shigella spp infection.

Also, this study has revealed that 1 patient $(0.9 \%)$, although asymptomatic, had Enterotoxigenic E. coli and Shigella spp isolated from their stool specimens. According to Okeke et al., 2000 and Opintan et al., (2010) healthy carriage of enteric pathogens in general and Enterotoxigenic E.coli in particular is high in many African studies. It is not surprising, therefore, to isolate this organism from apparently healthy individuals, as human infection caused by E.coli O157:H7 can present a broad clinical spectrum ranging from asymptomatic cases to death (Lim et al., 2010). Because asymptomatic cases can occur in outbreaks, there has been concern that persons with such infections could unwittingly spread infection to others. The existence of such asymptomatic cases during outbreaks has been well documented (Pavia et al., 1990; Belongia et al., 1993). Asymptomatic infections have also been demonstrated in family members and other close contacts of persons with hemolytic uremic syndrome or symptomatic $E$. coli $\mathrm{O} 157: \mathrm{H} 7$ (Marsh et al., 1992).

The rate of infection in relation to the total numbers of seasonal isolation of Enterotoxigenic E. coli and Shigella spp were documented by previous research to be high during the wet seasons of the year i.e. May through October of the four-year period of study. Only one confirmed Enterotoxigenic E. coli and Shigella spp isolations were made during this study which was conducted during the dry seasons. These findings agree with other studies (Boyce et al., 1995, Chapman, 2000) which show that human infections associated with Enterotoxigenic E. coli and Shigella spp seem to be more common during the summer months, with the majority of cases occurring during the months of May through September. Ostroff et al. (1989) suggested that the increased shedding of Enterotoxigenic E. coli and by cattle during summer months may contribute to a similar seasonal pattern of Enterotoxigenic E. coli associated food borne illness in humans. Thus it can be inferred that most food- borne and waterborne infections are commonest during the wet seasons of the year. Especially in Benue State, insanitary market places, over- flooded drainages and living environment as well as contaminated abattoir-work environment, could serve as sources of several bacterial infections.

\section{Conclusion}

The data from this present study indicate that certain predisposing factors such as source of drinking water, wet seasons of the year and asymptomatic carriage of infection can contribute to Enterotoxigenic E. coli and Shigella spp infection. Personal and environmental hygiene and adherence to good food handling practices represent the last line of defense for assuring prevention of Enterotoxigenic E. coli and Shigella spp infection.

\section{Recommendations}

Since the infection primarily occurs via fecal-oral route, drinking chlorine- treated water could be very useful and food hygiene measures like proper cooking of meat, consumption of pasteurized milk, washing fruits and vegetables especially those to be eaten raw There is therefore need to adopt modern sanitary methods which are discussed below to prevent the spread of Enterotoxigenic E. coli and Shigella spp infection, which include the following:

- It is recommended to maintain the health education activities on prevention of Enterotoxigenic E. coli and Shigella spp infection, which include both food industry and members of the general public

- Subsequent studies should be carried out in other university institutions since this study was limited to General Hospital Makurdi, Benue State

- Establish collaboration of overseas public health authorities in exchange of information and alert the food trade 
promptly once there is incident of food contamination with Enterotoxigenic E. coli and Shigella spp.

- Maintaining the surveillance program of Enterotoxigenic E. coli and Shigella spp infection in local markets and slaughterhouse

- Personal hygiene practices such as washing of hands after visiting the toilet and after eating food.

- Similar work should be carried out during the rainy season of the year as this was carried out during the dry season.

\section{Reference}

1. Ashkenazi, S., Levy, I., Kazaronovski V. (2003). Growing antimicrobial resistance of Shigella isolates. J Antimicrob Chemother 51:427-429

2. Beatty, M.E., Adcock, P.M., Smith, S.W. (2006). Epidemic diarrhea due to enterotoxigenic Escherichia coli. Clin Infect Dis; 42:329.

3. Belongia, E. A., Osterholm, M.T., Soler, J.T., Ammend, D.A., Braun, J.E. and Macdonald, K.L. (1993). Transmission of Escherichia coli O157: H7 infection in Minnesota child day-care facilities JAMA. 289: 883-888.

4. Bennish, M.L, Wojtyniak, B.J. (1991) Mortality due to shigellosis: community and hospital data. Rev Infect Dis; 13: 245-51.

http://en.wikipedia.org/wiki/Escherichia_c oli "Escherichia coli". CDC National

Center for Emerging and Zoonotic Infectious Diseases. Retrieved 2014-1002 .

5. Bennish, M.L. (1991). Potentially lethal complications of shigellosis. Rev Infect Dis; 13 Suppl 4:S319.

6. Boyce, T.G., Swerdlow, D.L., and Griffin, P.M. (1995). Current concepts: Escherichia coli O157:H7 and the hemolytic uremic syndrome. N. Engl. J. Med. 333: 364-368.

7. Center for Diseace Control and Prevention. (2006) Accessed $4^{\text {th }}$ March 2014http://www.cdc.gov/nczved/divisions/ dfbmd/diseases/shigellosis/

8. Chapman, P.A. (2000). Sources of Escherichia coli $\mathrm{O} 157$ and experiences over the past 15 years in Sheffield, U.K. J. Appl. Microbiol., (Symposium Suppl.) 88: 51S-60S.

9. Chompook, P., Samosornsuk, S., Von Seidlein, L., Jitsanguansuk, S., Sirima, N., Sudjai S, et al.( 2005) Estimating the burden of shigellosis in Thailand: 36month population-based surveillance study. Bull World Health Organ. ;83(10):739- 46.

10. Downes, F. P., \& Ito, K. (Eds.). (2001). Compendium of Methods for the Microbiological Examination of Foods (4th ed.). Washington, DC, USA: American Public Health Association.

11. Eckburg., P.B, Bik, E.M., Bernstein, CN., Purdom, E., Dethlefsen. L., Sargent, M., Gill, S.R., Nelson, K.E., Relman, D.A. (2005). "Diversity of the human intestinal microbial flora".Science 308 (5728): 1635-8. doi:10.1126/science.1110591.

12. Erqou, S. A., Teferra, E., Mulu, A., \& Kassu, A. (2007). A case of shigellosis with intractable septic shock and convulsions. Japanese Journal of Infectious Diseases, 60(5), 314-316.

13. Firdausi, Qadri, Ann-Mari Svennerholm, A. Faruque, S. G.(2005) Enterotoxigenic Escherichia coli in Developing Countries doi: 10.1128/CMR.18.3.465- 483. Clin. Microbiol. Vol. 18 no. 3 465-483

14. Frank, C., Werber, D., Cramer, J.P., Askar, M., Faber, M., \& Heiden, M. (2011).

Epidemic profile of Shiga-toxinproducing Escherichia coli O104:H4 outbreak in Germany. $N$ Engl $J$ Med. 10;365(19):1771-80. 
15. Gould, L.H., Bopp, C., \& Strockbine, N. (2009) Centers for Disease Control and Prevention (CDC). Recommendations for diagnosis of shiga toxin-- producing Escherichia coli infections by clinical laboratories. MMWRRecomm Rep. 16;58(RR-12):1-14.

16. Grondin, C., Imbert, P., Ficko C, Merens, A., Dutasta, F., Bigaillon, C. (2012) Shigella flexneri bacteremia in two immune-competent adult travelers. $J$ Travel Med.;19(4):258-60.

17. Johnson, T. J., \& Nolan, L. K. (2009). Pathogenomics of the virulence plasmids of Escherichia coli. Microbiology and Molecular Biology Reviews, 73(4), 750774.

18. Kotloff, K.L. (1999). Global burden of Shigella infections: implications for vaccine development and implementation of control strategies. Bulletin of the World Health Organization 77: 651-666.

19. Kotloff, K.L., Winickoff, J.P., Ivanoff, B. (1999) Global burden of Shigella infections: implications for vaccine development and implementation of control strategies. Bull World Health Organ; 77: 651-66.

20. Kroser, J.A.. (2013). Medscape Reference. Shigellosis Workup.

http://emedicine.medscape.com/article/182 767-workup Accessed 4 ${ }^{\text {th }}$ may 2014.

21. Kurjak, A., \& Chervenak, F. A. (Eds.). (2006). Textbook of Perinatal Medicine (2nd ed.). United Kingdom: Informa UK Ltd.

22. Levine, M.M. (1991). Shigellosis. In: Strickland GT, HuntersTropical Medicine. 7th Edition. Philadelphia, WB Saunders Co., 340-344.

23. Lim, J.Y., Yoon, J and Hovde, C.J. (2010). A brief overview of Escherichia coli O157:H7 and its plasmid O157. J. Microbiol. Biotechnol.20 (1):5-14.
24. Lukjancenko, O., Wassenaar, T.M., Ussery, D.W. (2010). "Comparison of 61 sequenced Escherichia coli genomes". Microb. Ecol. 60

25. Mandomando, I., Sigauque, B., Valles, X., Espasa, M., Sanz, S., \& Sacarlal, J. (2007). Epidemiology and clinical presentation of shigellosis in children less than five years of age in rural Mozambique. Pediatr Infect Dis $J . \quad$;26(11):1059-61.

26. Marsh, J., MacLeod, A.F., Hanson, M.F., Emmanuel, F.X.S, Frost, J.A and Thomas, A.A. (1992). A restaurant-associated outbreak of E coli O157infection. J. Publ. Health Med. 14: 78-83.

27. Marsh, J., MacLeod, A.F., Hanson, M.F., Emmanuel, F.X.S, Frost, J.A and Thomas, A.A. (1992). A restaurant-associated outbreak of E coli O157infection. J. Publ. Health Med. 14: 78-83.

28. Medicinenet. (2014). Shigella Infection. Accessed May $14 \quad 2014$ from www.medicinenet.com/shigella_infection/ article.htm

29. Nagy, B., \& Fekete, P. Z. (2005). Enterotoxigenic Escherichia coli in veterinary medicine. International Journal of Medical Microbiology : IJMM, 295(6-7), 443-454.

30. Nataro, J.P., Kaper, J.B. (1998) Diarrheagenic Escherichia coli. Clinical Microbiology Reviews, 11:142201.

31. Niyogi, S.K. (2007) Increasing antimicrobial resistance-an emerging problem in the treatment of shigellosis. Clin Microbiol Infect; 13: 1141-3.

32. Okeke, I.N., Ojo, O., Lamikanra, A. and Kaper, J.B. (2003). Etiology of acute diarrhea in adults in South Western Nigeria. J. Clin. Microbiol.41:4525-30.

33. Opintan, J.A., Bishar, R.A., Newman, M.J and Okeke, I.N. (2010). Carriage of diarrheagenic Escherichia coli by older 
children and adults in Accra Ghana. Trans R Soc Trop Med Hyg. 104 (7): 504-506.

34. Ostroff, S.M., Kobayashi, J. M., and Lewis, J.H. (1989). Infections with Escherichia coli O157: $\mathrm{H} 7$ in Washington State. The first year of statewide disease surveillance. JAMA. 262:355- 9.

35. Parashar UD, Bresee JS, Glass RI. The global burden of diarrheal disease in children. Bull World Health Organ. 2003; 81(4):236.

36. Parry, S.M, Salmon, R.L. Sporadic, STEC O157 infection: secondary household transmission in Wales. Emerg Infect Dis. 1998;4:657-61.

37. Path, P. (2013) Innovation in Enteric Vaccine Development: Addressing Bacterial Causes of Diarrhea. http://www.path.org/vaccineresources/shig ella-etec.php

38. Pavia, A. T., Nichols, C. R., Green, D. P., Tauxe, R. V., Mottice, S., Greene, K. D., Wells, J. G., Siegler, R. L., Brewer, E. D., Hannon, D and Blake, P. A. (1990). Hemolytic uremic syndrome during an outbreak of Escherichia coli O157:H7

infections in institutions for mentally retarded persons: clinical and epidemiological observations. J. Pediatr. 116:544-551.

39. Peirano, G., Souza, F.S,, Rodrigues, D.P.(2006) Frequency of serovars and antimicrobial resistance in Shigella spp. from Brazil. Mem Inst Oswaldo Cruz;101(3):245-50.

40. Pelletier, D.L., Frongillo, E.A., Jr, Schroeder, D.G., Habicht, J.P. (1995). The effects of malnutrition on child mortality in developing countries. Bull. World Health Organ.;73:443-448. [PMC free article] [PubMed]

41. Peng, J., Yang, J., Jin, Q. (2009). The molecular evolutionary history of Shigella spp. and enteroinvasive Escherichia coli. Infect Genet Evol:;9(1):147-52.
42. Public Health Agency of Canada. (2012, April). Escherichia coli. Retrevied from Public Health Agency of Canada website http://www.phac-aspc.gc.ca/lab bio/res/psds-ftss/escherichia-coli-toxeng.php

43. Qadri, F. (2005). "Enterotoxigenic Escherichia coli in developing countries: epidemiology, microbiology, clinical features, treatment, and prevention." Clinical Microbiology Reviews 18: 465483.

44. Reiss, G, Kunz, P. Koin, D and Keeffe E.B. Escherichia coli O157:H7

45. Safewateronline.com. Travelers' diarrhea". Accesed at $4^{\text {th }}$ March, 2014 from safewateronline.com http://web.archive.org/web/200806060328 48/http:/www.safewateronline.co m/travelers_d.htm

46. Shears, P. (1996). Shigella infection. Ann. Trop. Med. Parasitol. 90, 105-114.

47. Singh, K. (2009). Laboratory-acquired infections. Clinical Infectious Diseases : An Official Publication of the Infectious Diseases Society of America, 49(1), 142-147. doi:10.1086/599104

48. Singleton, P. (1999). Bacteria in Biology, Biotechnology and Medicine (5th ed.). Wiley. pp. 444-454. ISBN 0-471-98880-4.

49. Slutsker, L., Ries, A. A., Greene, K. D., Wells, J. G., Hutwagener, L. and Griffin, P. M. (1997). Escherichia coli O157:H7 diarrhea in the United States: Clinical and epidemiologic features. Ann. Intern. Med. 126:505-513.

50. Su, C and Brandt, L.J. (1995). Escherichia coli O157:H7 infections in humans. Ann. Intern. Med. 123: 698-714.

51. Sureshbabu, J. (2012). Medscape Reference. Shigella Infection Workup.

52. Sweeney, N. (1996). The Escherichia coli K-12 gntP gene allows E. coli F- 18 to occupy a distinct nutritional niche in the 
streptomycin-treated mouse large

intestine. Infect. Immun. 64, 3497-3503

53. Vaccine resource library, (2013) More about shigellosis and enterotoxigenic Escherichia coli (ETEC) Retrieved from http://www.path.org/vaccineresources/shig ella-etec info.php

54. Vogt, R.L., Dippold, L. (2005). "Escherichia coli O157:H7 outbreak associated with consumption of ground beef, June-July 2002". Public Health Rep $120 \quad$ (2): 174-8. PMC 1497708. PMID 15842119.

55. Wang, .H. (2009). Epidemiological study on an outbreak caused by E. coli O157:H7 in Jiangsu province. Chin $J$ Epidemiol 25(11):938-940

56. WebMD, Medical. (2012). Retrieved on July

06 , 2012 http://www.webmd.com/digestivedisorders/travelers-diarrhea? page $=3$

57. Wikipedia, the free encyclopedia (2014, January 30). FL: Wikimedia Foundation, Inc. retrieved January 30, 2014, from http://en.wikipedia.org/wiki/Shigella

58. World Health Organization, (2001). Antimicrobial resistance in shigellosis, cholera and campylobacteriosis. WHO/CDS/CSR/ DRS/2001.8. World Health Organization, Geneva, Switzerland.

59. World Health Organization. (2013). Diarrhoeal disease. Retrevied from World Health Organization website. http://www.who.int/mediacentre/factsheets /fs330/en/

60. Wright, A. (2005). Associate Professor of Food Microbiology University of Florida Food Science and Human Nutrition Department http://www.epi.ufl.edu/?q=node/38

61. Yabuuchi, E. (2002). Bacillus dysentericus (sic) 1897 was the first rather than Bacillus dysenteriae 1898. Int. J. Syst. Evol. Microbiol., 52, 1041-1041 